\title{
What are the determinants of investment in environmental R\&D?
}

Costa-Campi, M.T., Department of Economics and Chair on Energy Sustainability, Barcelona Institute of Economics (IEB), University of Barcelona. E-mail: mtcosta@ub.edu

García-Quevedo, J., Department of Economics and Chair on Energy Sustainability, Barcelona Institute of Economics (IEB), University of Barcelona. E-mail: jgarciaq@ub.edu. Tel.: 934021988.

Martínez-Ros, E., (corresponding author) Universidad Carlos III de Madrid. Departamento de Economía de la Empresa. E-mail: emros@emp.uc3m.es

\begin{abstract}
To face the challenges posed by climate change, environmental $R \& D$ and innovation are critical factors if we hope to cut emissions; yet, investment in environmental R\&D remains below the social optimum. The aim of this paper is to analyse the determinants of investment in environmental innovation and to detect the differences, if any, with the determinants of investment in general innovation. In addition, this paper examines the relationship between environmental innovation $R \& D$ expenditure and a range of policy instruments, including environmental regulation and other policy measures including $\mathrm{R} \& \mathrm{D}$ subsidies and environmental taxes. The empirical analysis is carried out for 22 manufacturing sectors in Spain for the period 2008-2013. To overcome problems of data availability, we construct a comprehensive database from different surveys. The main implications from our results are 1). Managerial strategy appears as a relevant driver of environmental $R \& D$ investments. 2) The establishment of a policy mix between environmental, energy and technological regulatory measures is recommended. 3) The promotion of self-regulation through actions that encourage companies to follow a policy that affects their energy efficiency and is environmentally friendly.
\end{abstract}

Key words: Environmental innovation, tax and demand instruments, panel data.

JEL: O30, Q50, Q58

Acknowledgments: We are grateful to Odín Costa for providing excellent research assistance. We thanks the suggestions from participants in the International Academic Symposium "Energy and Environmental Policy", IEB-UB and FUNSEAM, Barcelona, (Spain), 2 February 2016, "V Meeting on International Economics: "Energy and Environmental Challenges in a Globalized World", Villarreal (Castellón, Spain), 6-7 July, 2016 and the "7 ${ }^{\text {th }}$ Atlantic Workshop on environmental and Energy Economics", A Toxa (A Coruña, Spain), 27-28 June, 2016. We acknowledge financial support from the Chair of Energy Sustainability (IEB, University of Barcelona) and from the projects ECO2015-69107-R and ECO2015-65559 (MINECO / FEDER, UE). 


\section{INTRODUCTION}

The agreement reached in Paris in 2015 committed all country signatories to stem their greenhouse gas emissions over the coming century, with the objective of holding the increase in the global average temperature and, thereafter, of pursuing efforts to limit the temperature increase (UNFCCC, 2015). Europe meanwhile has revised its climate targets initially set for 2020. Thus, its 2030 framework for climate and energy calls for a $40 \%$ cut on 1990 greenhouse gas emissions compared to the 20\% established in 2020 (European Commission, 2014). All this is clear evidence of the global concern for climate issues and of the steps needed to improve the environmental performance of countries around the world. In facing up to this challenge, environmental R\&D and innovation represent key factors if emissions are to be cut. Indeed, the introduction of more ambitious targets requires stepping up current $R \& D$ and innovation efforts (European Commission, 2014).

Corporations are typically portrayed as being one of the main causes of the environmental problems the world faces, yet many firms are responding by adopting active roles in environmental management (Walker and Wan, 2012). While some firms merely advocate the importance of managing the environment and signal their commitment to it, others see their performance as an all-encompassing construct and tackle environmental and economic issues together by promoting green innovation. Increasing levels of public scrutiny, public pressure and public incentives, combined with stricter regulatory controls, induce firms to innovate with positive consequences for the environment (Bilbao-Osorio et al., 2012; Johnstone et al., 2008).

However, environmental innovation is affected by the problem of double externality (Rennings, 2000). The combination of the environmental externality and knowledge- market failures justifies the introduction of environmental and innovation policies to encourage the adoption of eco-innovations (Del Río et al., 2016). Although many of the determinants of environmental innovation are expected to be similar to those of general innovation (Rennings, 2000; Del Río, 2009), the empirical literature has in fact identified quite distinctive features in the case of ecoinnovation (Hojnik and Ruzzier, 2015; Del Río et al., 2016). Specifically, and as a result of this double externality problem, regulation makes eco-innovation different (Del Río et al., 2015).

There has been a recent rise in interest in determining the drivers of investment in environmental innovation (Hojnik and Ruzzier, 2015; Del Río et al., 2016). As such, the aim of this paper is to contribute to this growing body of literature and to analyse the determinants of investment in eco-innovation and to detect differences, if any, with the determinants of investment in general innovation. To this end, we undertake an analysis of the drivers of environmental R\&D. Indeed, while R\&D investment is one of the main variables used in the 
field of the economics of innovation to analyse the technological activity of firms, data constraints have hampered its use for examining the drivers of investment in eco-innovation.

The literature to date reports that demand, regulation and stakeholder factors play important roles in the generation of investment in this sector (Rennings, 2000; Wagner, 2008; Kesidou and Demirel, 2012). In this same line, this paper seeks to shed further light on the relationship between environmental innovation investment and different policy instruments governing environmental innovation, that is, environmental regulations and a set of policy measures that include R\&D subsidies and environmental taxes (Del Río, 2009; Horbach et al., 2012; Veugelers, 2012; Marin, 2014).

We report the results of an empirical analysis conducted for 22 manufacturing sectors in Spain for the period 2008-2013. The analysis of the determinants of R\&D investment using industrylevel data is especially common in the field of the economics of innovation (Cohen, 2010); however, to the best of our knowledge, such an analysis has yet to be performed for environmental R\&D or eco-innovation. Industries have different technological opportunities and differ in their degree of eco-innovativeness. To overcome the lack of data, we build a comprehensive database drawing on different surveys on innovation, environmental issues and policy instruments. The use of industry-level data, although giving rise to certain limitations compared to the use of firm-level data, allows us to exploit the advantages of using panel data models. As Del Río et al. (2016) point out, econometric analyses using panel data are recommendable but they are virtually absent from the analysis of the drivers of eco-innovation owing to the unavailability of adequate data.

The rest of this article is structured as follows. The next section reviews the literature. The third section presents the model and the variables and describes the data. The fourth section discusses the main results. The last section concludes and presents some policy recommendations.

\section{BACKGROUND}

Businesses are coming under increasing pressure to take an active role in the achievement of greening goals alongside their more traditional financial goals (Johnstone et al., 2008). Since one of the mechanisms firms can adopt in dealing with the changing environment is that of innovation (Schoonhoven et al., 1990), green innovation represents a suitable option for countering this mounting pressure and promoting a green, sustainable environment (De Marchi, 2012; Johnstone et al., 2008). 
The terms environmental innovation, green innovation and eco-innovation are used here synonymously (Tietze et al., 2011) and we adhere to the following common definition:

“(...) innovation is the production, assimilation or exploitation of a product, production process, service or management or business method that is novel to the organization (...) and which results, throughout its life cycle, in a reduction of environmental risk, pollution and other negative impacts of resources use (including energy use) compared to relevant alternatives" (Kemp and Pearson, 2007: 7).

We adopt a simple framework for separating the four determinants of eco-innovation identified in the literature: firm strategies, technology, market/demand and regulation (Horbach et al., 2012; Horbach and Rennings, 2013). For firms to develop environmental innovations, Rennings (2000) argues that technology-push and market-pull factors alone do not provide sufficient incentives. While society as a whole benefits from environmental innovations, the costs are borne by individual firms. Despite the fact that certain environmental innovations can be marketed successfully, a firm's ability to appropriate the profits from such an innovation can be hindered if environmental benefits have the character of a public good or the corresponding knowledge is easily accessible and copied. Technology and market factors alone do not provide sufficient incentives. Consequently, the regulatory framework for environmental policies becomes another important driver of environmental innovations (Green et al., 1994, Rennings, 2000; Rennings and Zwick, 2002; Brunnermeier and Cohen, 2003; Hojnik and Ruzzier, 2015). Here, we focus specifically on policy measures and firm strategies leaving all other factors as controls.

While the world is moving towards more sustainable development, and as environmental innovation reduces the impact on the environment (at the same time inducing a high demand, according to Wagner, 2008), green innovation remains relatively new and unknown to firms (Horbach et al., 2013). Thus, while various technologies have been developed for the renewable production of energy, including solar, wind, water, and biomass sources, these technologies remain unstable and far from perfect. This means many opportunities can still be exploited and firms that successfully develop and market their green innovations can profit from being among the first-movers in this sector and from establishing green standards. The absorption of internal and external knowledge could alleviate the problems of spillover effects on potential imitators, thus overcoming threats of imitation and concerns of appropriation.

As innovative output is the product of knowledge generating inputs (Griliches, 1979), we need to determine where firms search for knowledge inputs for their eco-innovations. Hence, here we pay particular attention to firms' sourcing strategies for green innovations, given that a successful innovation depends on how adept firms are at the identification of, deliberate search 
for, reaching out to, managing and implementing these promising sources (Cohen and Levinthal, 1990; von Hippel, 1988). If the wrong sourcing strategy is pursued, firms may easily lose their opportunities or competitive advantage. Thus, good knowledge sourcing can provide firms with a competitive strategy for investing in appropriate R\&D or new product development and so they are better able to provide green products and boost their sales.

Resource-based theory highlights the importance of using internal capabilities and resources to maintain the sustainability of competitive advantage (Chen 2008, Leonidou 2013). These resources entail human knowledge, information technology and capital. Investment in these resources will necessarily lead to greater environmental efforts. In line with these arguments, we therefore formulate the following hypotheses:

HIa: Investment in the production process to prevent pollution increases environmental $R \& D$.

$H 1 b$ : Investment in end-of-pipe solutions to prevent pollution increases environmental $R \& D$.

HIc: The acquisition of energy products increases environmental $R \& D$.

The green business literature usually draws a distinction between firms that adopt a proactive stance, and which consider a variety of forces other than government regulations, and firms that are compliance-driven and that merely seek to meet their legal requirements (Buysse and Verbeke, 2003). As Kemp et al. (1992) recognise, increasing investments in eco-innovation are influenced by a firm's capabilities - specifically, those related to organisational skills, source reduction, recycling, pollution prevention, and green product design. Recently, Demirel and Kesidou (2011) have identified a firm's organisational capabilities and its environmental management systems (EMS) as being key drivers of eco-innovation intensity. Stakeholders (internal and external) usually exert influence on managers to adopt accreditations or certifications as a way to improve reputations and therefore performance. Here, the introduction of different levels of EMS can act as one of several facilitator factors in both the development and adoption stages of eco-innovation. Among the EMS certifications (ISO 14001, ISO 9001 and EMAS), only ISO 14001 stimulates both stages (Hojnik and Ruzzier, 2015).

HId: The introduction of EMS stimulates environmental R\&D

The introduction of environmental regulations and the public funding of $R \& D$ are the first steps towards promoting the development of green technologies. Yet, in common with other types of innovation, the benefits of eco-innovations may accrue to society rather than solely to the adopter of these new technologies. The market failure of innovation in general is common in discussions concerning the Porter hypothesis, where the key issue is determining whether 
regulation drives innovation. In fact, polluting firms can benefit from environmental policies, on the understanding that well-designed, stringent environmental regulations can actually stimulate innovation (Porter and van der Linde, 1995).

Some authors argue that increased environmental regulations lead to higher costs (Walley and Whitehead, 1994), while Horbach and Rennings (2013) report no increase in employment when firms develop green innovations in response to regulations. Although the stringency of environmental policies leads to more end-of-pipe type technologies (Aragón-Correa and Sharma, 2003; Frondel et al., 2007; Hart, 1995), Rennings et al. (2004) show that the effect of these technologies on employment is negative. Other authors, including most notably Porter and van der Linde (1995), argue the contrary case. They claim that environmental regulations provide firms with increased opportunities, which are accompanied expansion and an increase in employment. Likewise, Costa-Campi et al. (2014) show that in the energy sector, norms and regulations governing the environment and matters of health and safety actually foster investment in $R \& D$.

In the case of the Spanish pulp and paper industry, Del Río (2005) identified regulatory pressure and corporate image as the main drivers of its adoption of cleaner technology. Frondel et al. (2007) and Arimura et al. (2007) report that general policy stringency is an increasingly important driver as opposed to simple policy instruments. Moreover, stringency is particularly important for end-of-pipe technologies. On the basis of this evidence, we disentangle general regulations from environmental regulations to capture this distinction.

Thus, we explicitly separate environmental regulation centred on controlling emissions from taxes. This classification (see Wagner, 2003) places the emphasis firmly on the environmental effectiveness of the instruments. Hence, the instruments that establish emission limits and standards can be classed as command-and-control type regulations (end-of-pipe), while environmental taxes and charges and tradable emission permits or certificates are classified as market-based instruments. The latter have an economic profile since they trigger static and dynamic efficiency and internalise environmental externalities in and between markets.

\section{H2: The use of pollution taxes increases environmental $R \& D$.}

\section{H3: The use of stringent regulations increases environmental $R \& D$.}

Finally, recent developments regarding technological change support the idea that the use of a portfolio of instruments can help economies not only reduce the production of dirty technologies but also provide incentives to the private sector to innovate and create new, clean technologies. The presence of public support in the form of subsidies is particularly critical for developing clean technologies in the early stages since this can neutralise the advantages of 
older base technologies (Veugelers, 2012). Acemoglu et al. (2012) show that, while a carbon price alone could deal simultaneously with both environmental and knowledge externalities, such a course of action would represent a more costly scenario in terms of its impact on economic growth. Similarly, the use of subsidies alone results in excessively high levels of subsidies, which results in their becoming a substitute for proactive action (Yang and Oppenheimer, 2007). Moreover, regulatory measures also help to alleviate the double externality phenomenon. Therefore, we include the use of public funds as a complement of the instruments discussed above for limiting climate change.

H4: The use of public funds increases environmental $R \& D$.

\section{MODEL, VARIABLES AND DATA}

\subsection{Model and variables}

To conduct the empirical analysis based on the framework presented above, we use the following model:

$R \& D_{i t}=\beta_{0}+\beta_{1} F_{i t}+\beta_{2} S_{i t}+\beta_{3} R_{i t}+\mu_{i}+e_{i t}$

where $R \& D$ refers to private environmental $R \& D$ expenditure and $F, S$ and $R$ are different sets of explanatory and control variables for R\&D investment, in general, and for environmental $\mathrm{R} \& \mathrm{D}$, in particular.

In the first set of variables, $\mathrm{F}$, we include those control variables that have been identified in the literature as being determinants of general $R \& D$ expenditure at the industry-level and which have also been included in empirical analyses of eco-innovation (Del Río, 2009; Cohen, 2010; Del Río et al., 2016). First, we include two characteristics of firms, albeit at the industry-level, that may drive general investment in $R \& D$ : namely, $R \& D$ personnel intensity and the participation of foreign capital. Second, in line with the literature, we use the amount of sales to control for demand. Third, industries differ in their technological opportunities. Although there is no clear consensus regarding how best to make this concept empirically operational, the usual method has been to classify the industries according to their scientific or technological field. Here, we need to control specifically for technological opportunities related to the environment because industrial sectors also differ significantly in the degree of eco-innovativeness (Del Río et al., 2016). As a proxy we use the importance attached by a firm to the reduction of the environmental impact as an objective of their innovation policy. The assumption is that the sectors with a high number of firms attaching considerable importance to this objective will have greater environmental technology opportunities. 
In the second set of variables, $S$, we include two types of investment to prevent pollution and a measure of the use of energy products as an intermediate input in the production process. In addition, we include information in relation to EMS (Demirel and Kesidou, 2011). These variables highlight the environmental strategies firms develop that may require investment in environmental R\&D. In the case of investments to prevent pollution, we consider investment in end-of-pipe solutions and investment in the production process separately. The former corresponds to the technological solutions that firms incorporate in the existing manufacturing process and which are not essential parts of it. As such, the degree of technical advance represented by these investments is quite low as they are mainly incremental innovations. In contrast, investments in the production process correspond to new or substantially modified production facilities and they represent an integral part of the production process aimed at reducing pollution (Demirel and Kesidou, 2011).

Finally, we include a set of variables, $R$, to examine the effect of different policy measures on the promotion of environmental R\&D. Many papers stress the importance of policy support and regulation for promoting eco-innovation (Del Río, 2009; Popp et al., 2010; Horbach et al., 2012; Veugelers, 2012; Marin, 2014). To promote environmental R\&D, governments have a portfolio of instruments at their disposal and, as discussed in the previous section, they include the public financing of private $R \& D$, energy and environmental taxes and environmental regulation. In the case of this first variable, the amount of public subsidies specifically granted to environmental $\mathrm{R} \& \mathrm{D}$ is not reported and, so, we employ, by way of a proxy, total public support to business $R \& D$. Second, we distinguish between specific energy taxes and taxes with environmental objectives (pollution and resources). Finally, in line with Constantini and Crespi (2008) and Marin (2014), we use environmental pressures, measured in terms of air emissions of $\mathrm{CO} 2$, as a proxy for environmental regulation.

In addition to these explanatory variables, we take into account time-invariant characteristics through random effects $\mu$ i and time effects using time dummies to control for business cycle effects common to all industries.

\subsection{Data}

Empirical analyses of environmental technological change have to contend with constraints on data availability (Del Río, 2009; Veugelers, 2012). These limitations refer equally to the dependent and the explanatory variables. Many variables have been used to proxy environmental innovation (Del Río, 2009), although, as in general analyses of the determinants of innovation, arguably the three most accurate are two output measures - namely, patents and the introduction of new products and processes - and one input measure - namely, R\&D investment. 
Patents have specific limitations for measuring eco-innovations (Veugelers, 2012). However, direct data on eco-innovations adhering to the Oslo Manual (OECD, 2005) are only available for the period 2006-2008 for the countries that in 2009 conducted a separate module on ecoinnovation in their respective Community Innovation Surveys (Horbach, 2014). From these data, a number of empirical analyses have been carried out for specific countries (see, among others, Horbach et al., 2012; Veugelers, 2012; Horbach et al., 2013).

In this paper, we use environmental $R \& D$ investment at the industry-level for a set of manufacturing sectors as our dependent variable. The determinants of total $R \& D$ investment at both firm- and industry-levels have been extensively examined in the literature on the economics of innovation (Cohen, 2010). However, data on environmental $R \& D$ are very scarce (Horbach, 2014; Marin, 2014) because data on private R\&D expenditure are not usually reported by technology and tend only to be available by economic sector (Veugelers, 2012).

However, in the Spanish version of the Community Innovation Survey (CIS), since 2008 firms have been asked to classify their internal $R \& D$ expenditure according to its socio-economic objective, in line with the criteria employed in the Frascati Manual (OECD, 2002). Specifically, firms are required to distribute their $R \& D$ expenditure between fourteen socio-economic objectives, according to the purpose of the R\&D programme or project. One of these objectives is the control and care of the environment and it is this which allows us to know the amount of environmental $R \& D$ investment for 22 sectors. According to the information provided by the Spanish Institute of Statistics, roughly 3\% of private R\&D investment was devoted each year to this environmental objective in the period 2008-2013 by the whole of Spain's industry. Although all sectors reported investing in environmental $R \& D$, there were significant differences between them. The main investors, however, were Repair and installation of machinery and equipment (10.9\% in 2013), Paper, publishing and printing (9.3\% in 2013), Nonmetallic mineral products $(8 \%)$ and Metal products $(5.5 \%)$.

In addition to the limitations affecting the dependent variable, empirical analyses in this field also face difficulties obtaining information about the explanatory variables. However, as stressed in the theoretical framework (Horbach et al., 2013), different explanatory variables, including policy instruments, need to be taken into consideration. In this paper, we build a comprehensive dataset for 22 manufacturing sectors for the period 2008-2013 from six surveys, five conducted by the Spanish Institute of Statistics (INE) and one by the International Organisation for Standardisation (ISO) (see Table 1 and Table A.1 for general and industrylevel descriptive statistics respectively and Table A.2 for the definitions of the variables and the sources). They are: 
a) Innovation in Companies Survey (the Spanish version of the CIS). This survey, together with the information on total internal $R \& D$ and environmental $R \& D$, provides information about the main characteristics of the technological innovation of firms and sectors. Since 2002 the Innovation in Companies Survey has been carried out in Spain annually in coordination with the Statistics on R\&D activities survey with a single questionnaire for the firms. The sample of approximately of 40,000 firms includes companies that can potentially develop R\&D activities, companies with over 200 employees and a random section drawn from the Central Company Directory (CCD). In our database we have used the information published by the Spanish Institute of Statistics for industrial sectors. The information of this survey has been frequently used to carry out empirical analysis on R\&D and innovation (see, among others, De Marchi, 2012; Segarra and Teruel, 2014; Marzucci and Montresor, 2017).

b) The Industrial Companies Survey. This survey collects annual information on the main characteristics of the firms and sectors, including number of employees, sales and export figures. It also collects information on the acquisition of intermediate inputs, including those of electricity, gas and other energy products.

c) The Environmental Protection Activities Survey. This survey provides information on expenditure by firms from the industrial sectors on environmental protection including that spent on reducing or eliminating the emission of atmospheric pollutants and treating solid waste.

d) The Environmental Tax Account. This collects information on taxes whose base is associated with some material that has a proven and specific negative impact on the environment. From this survey we draw information about energy and pollution taxes by industrial sector.

e) The Air Emissions Account. This presents data about contaminating emissions into the atmosphere. From this survey we draw information about emissions of carbon dioxide by industrial sector.

f) Finally, we include information about environmental management systems. Specifically, we use ownership of an approved ISO 14001 that, as pointed by Kesidou and Demirel 2002 and Testa et al. (2014), is one of the most widely disseminated forms of environmental management system together with the Eco Management and Audit Scheme (EMAS). The ISO 14001 can be used by any firm, regardless of its activity, that aims to set up an environmental management system and obtain a certification for their productive process. ISO 14001 has been frequently used in empirical analysis on the drivers of eco-innovations 
as two recent reviews of the literature show (Del Río et al., 2016; Hojnik and Ruzzier, 2015). It has also been found that it is effective in stimulating environmental R\&D (Demirel and Kesidou, 2011). Information regarding ISO 14001 accreditation for Spain's manufacturing sector was provided directly by the International Organisation for Standardisation, but has only been available since 2009 .

[Insert Table 1 around here]

\section{RESULTS}

We use a panel data set of 22 Spanish manufacturing sectors for the period 2008-2013 to study the main drivers of $R \& D$ investment. We present our main results in two tables that separate pollution prevention strategies (Table 2) from regulatory and policy measures (Table 3). In table 2, we try to answer the hypotheses $\mathrm{H} 1$ while in table 3 we report the findings of our hypotheses $\mathrm{H} 2-\mathrm{H} 4$.

Our findings consider, first, the heterogeneity problem of different levels of $R \& D$ investment across industries and, second, the endogeneity problems associated with the reverse causality of generic subsidies or the investment in prevention measures as part of the production process. Both problems are addressed by employing a variety of methods and checked using robustness tests. The procedures employed are explained below.

We estimate a random effects model and, as we are able to confirm that some of our $\mathrm{X}$ variables are correlated with the unobserved firm effect, we propose modelling this unobserved firm effect explicitly using $\mu \mathrm{i}=\lambda \overline{\mathrm{X}} \mathrm{I}+\mathrm{vi}$, where $\mathrm{v}$ is not correlated with the error term $\mathrm{e}_{\mathrm{it}}$ and $\overline{\mathrm{X}}$ represents the sectoral mean of exogenous variables.

In addressing the endogeneity problem we include the above approach in our estimation, and we check the robustness of subsidies and investment in prevention measures among the production process variables in our model using several methods, including instrumental variables and the Hausman-Taylor estimator.

Our main findings can be summarised as follows. When we consider each environmental strategy in isolation, we observe that they matter as drivers of $R \& D$ investment, confirming our hypotheses H1a-H1d. These positive effects coincide with the link Cohen and Levinthal (1990) identified between sources of knowledge and competition and with Kesidou and Demirel's (2012) recognition of organisational capabilities and environmental systems as drivers of ecoinnovation. We find no quantitative differences between investment in the production process 
and in end-of-pipe solutions; however, the role of acquisition of energy products is a more relevant factor. This implies that the weight of inputs may be crucial in a firm's R\&D budget while other investments are broader and less clearly defined. In addition, environmental management systems (ISO 14001) are also significant and positive as literature claims. Since the EMS is a worldwide tool potentially applicable by any kind of organization in order to improve the management of its environmental performance (Testa et al., 2014), stakeholders will push for investment to improve performance, as well. This is a way of introducing selfregulation since proactiveness in being greener could be a strategy in the decision making of managers.

These results inform us about our hypotheses that firm's strategies produce increases in investment in environmental $R \& D$. In particular, the combination of inputs acquisition and the adoption of EMS allow companies to place emphasis on the first phase of eco-innovation: the development/innovation stage.

[Insert Table 2 around here]

When controlling for correlation using the Mundlak method, we obtain the same results in terms of magnitude. Note that in the estimation we take into account several controls, including time, and various firm controls, including foreign and human capital, demand, and technological opportunity. In these controls, only the human capital variable is relevant in terms of its effect on $R \& D$ investment. This variable is a ratio of the number of employees engaged in $R \& D$ to total employees and as such is a measure of the intensity of the effort dedicated to innovation. In the remaining results, this variable always presents a marked effect. It also underlines the importance of human resources as resource-based theory claims.

Our main findings regarding regulatory and policy measures are presented in Table 3. Application of the Mundlak method again reveals them to be robust and we observe that the use of (non-specific) subsidies has a greater effect on R\&D investment than the use of the other regulatory instruments, confirming $\mathrm{H} 4$. It would seem it is more beneficial to provide opportunities than it is to punish. However, if punishments have to be meted out, it appears that it is preferable to use specific tools related to the environment or environmental taxes. Hence, regulatory pressures play an important role in alleviating the dual-externality problem.

[Insert Table 3 around here]

In the last column of Table 3, we show the results when the estimation includes all the policy measures. These confirm our previous findings, namely, that regulatory stringency and environmental taxes are important but that subsidies are twice as important in promoting ecoinnovation. Our hypotheses about the importance of direct support are confirmed with this 
result. As Yang and Oppenheimer (2007) pointed out the use of subsidies complements the pollution specific action.

As a final exercise, we undertake several robustness checks. The first concerns the possibility that some variables, such as environmental norms and stringency, act as moderators of subsidies. To verify this, we estimate several interactions but none of them produce significant results. In a second step, and in order to test the robustness of the model, we sought to replicate the same model but using internal R\&D as our dependent variable and leaving environmental expenses out of the estimation. The results in this case confirm the expectations that some determinants are specific to environmental $R \& D$. In this estimation for non-environmental R\&D, public support continues to be significant and positive but pollution taxes are not significant and the parameter for energy taxes is significant and negative. A further result worth highlighting is that human capital is no longer relevant but the participation of foreign capital is in the development of $R \& D$ investment. With these estimations we confirm that there are significant differences between the drivers of environmental R\&D investment and those of general, non-environmental, $R \& D$ and that it is necessary to make an effort to identify the specific drivers of eco-innovation. In addition, to enhance environmental $R \& D$ requires the development of tangible and intangible resources (Sarkis et al., 2010).

The results of the estimations on policy instruments ( $R \& D$ subsidies and taxes) comparing $R \& D$ innovation and $\mathrm{R} \& \mathrm{D}$ in general suggest that to confront the double externality problem of environmental innovation more than one instrument is required. Our estimations show that $R \& D$ subsidies and pollution taxes have a positive effect on environmental innovation while pollution taxes are not significant for non-environmental $R \& D$. Unfortunately there is no available information on specific subsidies to environmental R\&D projects that would allow a more precise analysis of policy instruments and a more detailed exploration of how to deal with the double externality of environmental innovation.

Finally, we examined the endogeneity problem identified earlier by considering two variables that might be responsible for this problem: namely, subsidies and investment in the production process. In the following, we describe the several steps employed. First, we substitute these variables with their respective lags to detect the possible time causality. Second, we use the IV method considering as our instrument the lags of the variables. Third, we apply the HausmanTaylor method. The difference between these two methods lies in the respective assumptions they make about the correlation with the error term. The estimators implemented using the IV method assume that a subset of the explanatory variables in the model are correlated with the idiosyncratic error $\mathrm{e}_{\mathrm{it}}$. In contrast, the Hausman-Taylor and Amemiya-MaCurdy estimators assume that some of the explanatory variables are correlated with the individual-level random 
effects, but that none of the explanatory variables are correlated with the idiosyncratic error. Our results are reported in Table 4.

[Insert Table 4 around here]

Our findings seem to suggest that investment in the production process, in contrast to subsidies, is not correlated with the unobserved fixed effect. This means that some reverse causality between the application of subsidies and investment in environmental $R \& D$ exists leading to policy implications. These results on the use of subsidies as an incentive to environmental investment suggest that government support is focused on the intensive margin. That means to those firms that undertake $R \& D$ activities on a continuous basis. These $R \& D$ subsidies are direct aid that public agencies grant to the screened companies that win R\&D projects in competitive calls.

\section{CONCLUSIONS AND POLICY IMPLICATIONS}

This paper has sought to contribute to the empirical literature examining the drivers of environmental innovation. Indeed, there is considerable interest in identifying the determinants of eco-innovation given that environmental technological advances are essential to face the challenges posed by climate change.

This paper has focused its attention specifically on the determinants of environmental R\&D. Although $R \& D$ is one of the main variables considered when analysing the economics of innovation, data constraints substantially limit empirical analyses of investment in environmental R\&D. To examine these determinants, therefore, we have compiled a database with information taken from different sources concerning innovation, economic and environmental activities and the characteristics of firms and sectors. In addition, we have included all information available on policy instruments designed to promote environmental R\&D.

In line with the literature, we have adopted a simple framework for separating the determinants of eco-innovation: namely, firm strategies, technology, market and regulations. Using this framework, we have formulated several hypotheses regarding the impact of firms' strategies and policy instruments on investment in environmental R\&D.

To test these hypotheses, we have carried out an empirical analysis with panel data for 22 manufacturing sectors in Spain for the period 2008-2013. In conducting this analysis we have taken into account various concerns regarding the heterogeneity of $R \& D$ investment across industries and potential endogeneity attributable to the reverse causality of some of the 
variables. The empirical analysis confirms the existence of distinctive features in relation to the drivers of investment in eco-innovation.

First, we find a positive relationship between investment to prevent pollution and R\&D efforts. This result holds for both types of investment, that is, investment in the production process and in end-of-pipe solutions. We also find a positive relationship between the greater use of energy products as an intermediate input in the production process and investment in environmental R\&D. Managerial strategy appears as a relevant driver of environmental R\&D investments.

Second, instruments of innovation policy as well of environmental policy have a positive impact on levels of investment in environmental $R \& D$. The results show that $R \& D$ subsidies have a significant impact on promoting $R \& D$ specifically devoted to environmental concerns. The empirical analysis also shows that specific environmental taxes that target pollution and the use of resources also have a positive effect on environmental R\&D. However, the same does not hold true for general energy taxes. Finally, the stringency of regulations has a positive effect on levels of environmental $R \& D$. The results of the estimations on policy instruments comparing environmental $R \& D$ with the drivers of total $R \& D$ expenditure, where pollution taxes are not significant, suggest that more than one instrument is required to deal with the double externality problem of environmental innovation. As the literature points out (Popp et al., 2010) environmental and technology policies are more effective when they operate in tandem.

All in all, the results underscore the importance of environmental R\&D investment to achieve the goal of climate change mitigation. What this requires is a combination and mix of energy policies, the promotion of $\mathrm{R} \& \mathrm{D}$, regulatory and fiscal policies all which complement one another, and the promotion of self-regulation and dissemination of information.

The policy of promoting environmental $R \& D$ investment reduces technological and market uncertainty of innovative companies, on the one hand, and on the other drives the demand for innovation that encourages users to adopt the use of environmentally-friendly technology.

Given that environmental innovations are affected by the problem of double externality, implementation of environmental regulation to help foster innovation, in addition to traditional policies, becomes necessary. In this sense, a first aspect to be highlighted is the need for integration between environmental and energy measures and those designed to foster innovation. Therefore, the establishment of a policy mix between environmental, energy and technological regulatory measures is recommended, given the interconnectedness of developing environmental innovations (Crespi et al., 2015). 
A second aspect is that the policy should be part of the energy policy and a third aspect is that it should encourage self-regulation, the consolidation of which is crucial in reaching the goal of climate change mitigation.

Implementation of this policy requires a broad range of instruments whose design must be based on a common goal which is to improve the environment. One might distinguish six types of measures. First, incentives in the form of subsidies to promote environmental R\&D investment, including improvements in energy use. Second, market-based instruments such as the European Union Emissions Trading System. Third, environmental taxes and fees. Fourth, management and control measures such as standards setting, requiring companies to comply with environmental standards both in their production processes and products and their suppliers. Fifth, the promotion of self-regulation through actions that encourage companies to follow a policy that affects their energy efficiency and is environmentally friendly. Self-regulation, individually or agreed upon by a group of enterprises, is essential to achieving the objectives of environmental control. And sixth and last, the above measures should be accompanied by information and awareness programs.

To sum up, according to the results obtained environmental policy is fundamental in mitigating climate change. Therefore countries must treat it as a strategic policy. In addition, it has a transversal (affects all sectors and all phases of the production process) and also a mixed character (includes all kinds of instruments), especially if its purpose is to enhance environmental R\&D (Quitzow, 2015).

Environmental policy requires a portfolio of instruments. As our results show the use of subsides to $R \& D$, investment incentives to environmentally beneficial technologies and pollution taxes are the right tools to foster environmental $R \& D$. These tools for intervention can also have positive effects both on production processes and end-of pipe investments. It is also necessary to focus on the development of intangible assets. These policies can help the development of managerial capabilities that allow opportunities to be identified in the environmental performance of companies.

These actions should be part of a stringent regulation that promotes environmental innovation among companies. A regulation in favor of environmental $R \& D$ can provide competitive advantages, according to the work of Porter and Van der Linde (1995). The opportunity to be a market leaded could be afforded by stringent environmental regulations (Beisse and Rennings, 2005). These regulations may be seen as policy measures to encourage self-regulation, since they incentivize companies to comply with them, and even surpass them, to achieve greater benefits. However, some limits exist to the stringency of environmental regulation that, if surpassed, can turn this opportunity into a problem (relocation or regulatory distance with other 
markets) (Antonietti et al., 2016; Dechelezpetre et al., 2015). Therefore, as in the case of seeking an optimal combination of policy tools to promote environmental innovation, an optimal level of environmental regulation is also required.

The application of a portfolio of policies for the promotion of environmental R\&D also generates expectations in stakeholders that reinforce its effect. In this way, if environmental innovation promotion exists, investors are more attracted to this type of investment, while penalizing the allocation of resources towards more polluting technologies. Therefore, the companies themselves are motivated to develop environmental $R \& D$ to attract new sources of funding or maintain the existing ones. Environmental regulation and economic instruments for the promotion of environmental $\mathrm{R} \& \mathrm{D}$ can be considered as elements that favor self-regulation by companies. 


\section{REFERENCES}

Acemoglu, D., Aghion, P., Bursztyn, L., Hemous, D. (2012). The environment and directed technical change. American Economic Review 102(1), 131-166.

Antonietti, R., De Marchi, V. and Di Maria, E., 2016. Governing offshoring in a stringent environmental policy setting: Evidence from Italian manufacturing firms. Journal of Cleaner Production, in press, available online 17 November 2016.

Arimura, A. Hibiki, N. Johnstone, N. 2007. An empirical study of environmental R\&D: what encourages facilities to be environmentally innovative? In N. Johnstone (Ed.), Environmental Policy and Corporate Behaviour, Edgar Elgar (2007), pp. 142-173.

Aragón-Correa, J. A., \& Sharma, S. 2003. A contingent resource-based view of proactive corporate environmental strategy. Academy of Management Review, 28(1): 71-88.

Beise, M. and Rennings, K., 2005. Lead markets and regulation: a framework for analyzing the international diffusion of environmental innovations. Ecological economics, 52, 5-17.

Bilbao, Osorio, B., Blanke, J., Crotti, R., Hanouz, M.D., Fidanza, B., Geiger, T., Ko, C., \& Serin, C. 2012. Chapter 1.2: Assessing the sustainable competitiveness of nations: The global competitiveness report 2012-2013. World Economic Forum 2012.

Brunnermeier, S. and Cohen, M. 2003. Determinants of environmental innovation in US manufacturing industries, Journal of Environmental Economics and Management 45, 278-293

Buysse, K., \& Verbeke, A. 2003. Proactive environmental strategies: A stakeholder management perspective. Strategic Management Journal, 24(5): 453-470.

Cohen, W., 2010. Fifty years of empirical studies of innovative activity and performance, in: Hall, B., Rosenberg, N. Handbook of the Economics of Innovation, Elsevier.

Cohen, W., and Levinthal, D. 1990. Absorptive Capacity: A New Perspective on Learning and Innovation, Administrative Science Quarterly 35, 128-152.

Constantini, V., Crespi, F., 2008. Environmental regulation and the export dynamics of energy technologies. Ecological Economics 66, 447-460.

Costa-Campi, M. T.; Duch-Brown; N.; García-Quevedo, J. 2014, R\&D drivers and obstacles to innovation in the energy industry. Energy Economics 46, 20-30.

Crespi, F., Ghisetti, C., \& Quatraro, F. 2015. Taxonomy of implemented policy instruments to foster the production of green technologies and improve environmental and economic performance, Working Paper no 90. WWWFOREUROPE.

Chen, Yu-Shaun, 2008. The driver of green innovation and green image-green core competence. Journal of Business Ethics 81(3), 531-543.

Dechezleprêtre, A., Neumayer, E. and Perkins, R., 2015. Environmental regulation and the cross-border diffusion of new technology: Evidence from automobile patents. Research Policy, 44, 244-257.

De Marchi, V., 2012. Environmental innovation and R\&D cooperation: Empirical evidence from Spanish manufacturing firms. Research Policy 41, 614-623.

Del Río, P., 2009. The empirical analysis of the determinants for environmental technological change: A research agenda. Ecological Economics, 68(3), 861-878.

Del Río, P., Peñasco, C., and Romero-Jordán, D., 2015. Distinctive features of environmental innovators: an econometric analysis. Business Strategy and the Environment, 24(6), 361-385. 
Del Río, P., Peñasco, C., and Romero-Jordán, D., 2016. What drives eco-innovators? A critical review of the empirical literature based on econometric methods. Journal of Cleaner Production, $112,2158-2170$.

Demirel, P., Kesidou, F., 2011. Stimulating different types of eco-innovation in the UK: Government policies and firm motivations. Ecological Economics 70, 1546-1557.

European Commission, 2014. COM(2014) 15 final. A policy framework for climate and energy in the period from 2020 to 2030. European Commission.

Frondel, M., Horbach, J. and Rennings, K., 2007. End-of-pipe or cleaner production? An empirical analysis of environmental innovation decisions across OECD countries. Business Strategy and the Environment 16, 571-584.

Green, A. McMeekin, A. Irwin. 1994. Technological trajectories and R\&D for environmental innovation in UK firms, Futures, 26: 1047-1059

Griliches, Z. 1979. Issues in Assessing the Contribution of Research and Development to Productivity Growth, 10(1), 92-116.

Hart, S.L. 1995. A natural-resource-based view of the firm. Academy of Management Review, 20(4): 874-907.

Hojnik, J., and Ruzzier, M., 2015. What drives eco-innovation? A review of an emerging literature. Environmental Innovation and Societal Transitions, forthcoming. Available on-line.

Horbach J, Rammer C, Rennings K., 2012. Determinants of eco-innovations by type of environmental impact - the role of regulatory push/pull, technology push and market pull. Ecological Economics 78, 112-122.

Horbach, J., Rennings, K., 2013. Environmental innovation and employment dynamics in different technology fields - an analysis based on the German Community Innovation Survey 2009. Journal of Cleaner Production 57, 158-165.

Horbach, J., Oltra, V., Belin, J. 2013. Determinants and specificities of eco-innovations compared to other innovations - An econometric analysis for the French and German Industry based on the Community Innovation Survey, Industry and Innovation, 20, 523-543.

Horbach, J., 2014. Determinants of Eco-innovation from a European-wide Perspective - an Analysis based on the Community Innovation Survey, SEEDS Working Paper 7/2014.

Johnstone, N., Hascic, I, and Ostertag, K. 2008. OECD studies on environmental innovation: Environmental policy, technological innovation and patents. Paris: OECD Publishing.

Kemp, R., Pearson, P. 2007. Final Report of the MEI project measuring eco-innovation. MEI Porject number 044513. Deliverable 15.

Kesidou, F, Demirel, P. 2012. On the drivers of eco-innovation: Empirical evidence from the UK. Research Policy 41, 862-870.

Leonidou, L. C., Constantinos, L. N., Fotiadis, T.A., Athina, Z., 2013. Resources and capabilities as drivers of hotel environmental marketing strategy: implications for competitive advantage and performance. Tourism Management 35, 94-110.

Marin, G., 2014. Do eco-innovations harm productivity growth through crowding out? Results of an extended CDM model for Italy. Research Policy 43. 310-317.

Marzucchi, A., Montresor, S. 2017. Forms of knowledge and eco-innovation modes: Evidence from Spanish manufacturing firms, Ecological Economics 131, 208-221.

OECD, 2002. Frascati Manual: Proposed standard practice for surveys on research and experimental development. OECD, Paris. 
OECD, 2005. Oslo Manual. The measurement of scientific and technological activities. Proposed guidelines for collecting and interpreting technological innovation data. $3^{\text {rd }}$ Edition. OECD Publishing.

Popp, D., Newell, R., Jaffe, A., 2010. Energy, the environment, and technological change in Hall, B., Rosenberg, N. Handbook of the Economics of Innovation, Elsevier, pp. 873-937.

Porter, M. E., Van der Linde, C., 1995. Green and competitive: ending the stalemate. Harvard Business Review, 73, 120-134.

Quitzow, R., 2015. Assessing policy strategies for the promotion of environmental technologies: A review of India's National Solar Mission. Research Policy, 44, 33-243.

Rennings, K., 2000. Redefining innovation-eco-innovation research and the contribution from ecological economics. Ecological economics, 32(2), 319-332.

Rennings, K., and Zwick, T. 2002. Employment impact of cleaner production on the firm level: Empirical evidence from a survey in five European countries. International Journal of Innovation Management, 6: 319-342.

Rennings, K., Ziegler, A., and Zwick, T. 2004. The effect of environmental innovations on employment changes: An econometric analysis. Business Strategy and the Environment, 13(6): 374-387.

Sarkis, J., González-Torre, P., Adenso-Díaz, B. 2010. Stakeholder pressure and the adoption of environmental policies: the mediating effect of training. Journal of Operations Management 28, 163-176.

Segarra, A., Teruel, M., 2014. High-growth firms and innovation: an empirical analysis for Spanish firms. Small Business Economics 1-17.

Schoonhoven, C., Eisenhardt, K., and Lyman, K. 1990. Speeding products to market: Waiting time to first product introduction in new firms. Administrative Science Quarterly, 35: 177-207.

Testa, F., Rizzi, F., Daddi, T., Gusmerotti, N. M., Frey, M. \& Iraldo, F. 2014. EMAS and ISO 14001: the differences in effectively improving environmental performance. Journal of Cleaner Production 68, 165-173.

Tietze, F., Schiederig, T., and Herstatt, C. 2011. What is green innovation? A quantitative literature review. Paper presented at the XXII ISPIM Conference, Hamburg.

UNFCCC, 2015. "Paris Agreement". United Nations Framework Convention on Climate Change. FCCC/CP/2015/L.9/Rev.1.

Veugelers R., 2012. Which policy instruments to induce clean innovating? Research Policy 41, $1770-1778$.

Von Hippel, 1988. The Sources of Innovation, Oxford University Press.

Wagner, M. 2003 "The Porter hypothesis revisited: a literature review of theoretical models and empirical tests". Research Memorandum Center for Sustainability Management (SM). University of Lüneburg. Germany.

Wagner, M. 2008. Empirical influence of environmental management in innovation: evidence from Europe. Ecological Economics 66, 392-402.

Walley, N., and Whitehead, B. 1994. It's Not Easy Being Green. Harvard Business Review 72, $3,46-52$.

Walker, K., and Wan, F. 2012. The harm of symbolic actions and green-washing: Corporate actions and communications on environmental performance and their financial implications. Journal of Business Ethics, 109, 227-242.

Yang, C., Oppenheimer, M. 2007. A "Manhattan Project" for climate change? Climatic Change 80: 199-204. 
Table 1. Descriptive Statistics

\begin{tabular}{|l|c|c|c|c|c|}
\hline & Obs. & Mean & Std. Dev. & Min & Max \\
\hline $\begin{array}{l}\text { Environmental R\&D (in } \\
\text { logs) }\end{array}$ & 138 & 12.210 & 1.491 & 7.015 & 14.684 \\
\hline Sales (in logs) & 138 & 18.417 & 1.221 & 16.112 & 20.937 \\
\hline $\begin{array}{l}\text { Human RD personnel } \\
\text { intensity }\end{array}$ & 138 & 3.634 & 3.797 & 0.520 & 13.829 \\
\hline Foreign capital & 137 & .114 & 0.095 & .007 & .667 \\
\hline $\begin{array}{l}\text { Log of investment in } \\
\text { production process }\end{array}$ & 132 & 15.129 & 1.951 & 9.375 & 18.201 \\
\hline $\begin{array}{l}\text { Log of investment in } \\
\text { end-of-pipe }\end{array}$ & 131 & 14.945 & 2.213 & 7.850 & 18.596 \\
\hline $\begin{array}{l}\text { Log of acquisition of } \\
\text { energy products }\end{array}$ & 138 & 12.521 & 1.239 & 10.486 & 14.731 \\
\hline $\begin{array}{l}\text { Importance to reduce } \\
\text { environmental impact }\end{array}$ & 138 & 25.544 & 14.406 & 2.7 & 100 \\
\hline Log of subsidies & 138 & 8.799 & 1.484 & 3.178 & 12.211 \\
\hline Log of energy taxes & 90 & 10.777 & 1.128 & 8.160 & 13.411 \\
\hline Log of pollution taxes & 60 & 7.797 & 1.712 & 4.605 & 10.211 \\
\hline Log of CO2 emissions & 90 & 7.132 & 1.863 & 3.114 & 10.648 \\
\hline Log of ISO14001 & 80 & 5.389 & 1.152 & 2.565 & 7.046 \\
\hline
\end{tabular}


Table 2. Effect of Environmental Strategies on Pollution Prevention

\begin{tabular}{|c|c|c|c|c|c|c|c|c|c|}
\hline & \multicolumn{3}{|c|}{ Random effects } & \multirow[b]{2}{*}{ EMS } & \multicolumn{3}{|c|}{ RE-Mundlak } & \multirow[b]{2}{*}{ EMS } & \multirow[b]{2}{*}{ TOTAL } \\
\hline & $\begin{array}{l}\text { Invest in the } \\
\text { prod. process }\end{array}$ & $\begin{array}{c}\text { Invest end- } \\
\text { of-pipe }\end{array}$ & $\begin{array}{l}\text { Acq. of energy } \\
\text { products }\end{array}$ & & $\begin{array}{l}\text { Invest in the } \\
\text { prod. process }\end{array}$ & $\begin{array}{c}\text { Invest end- } \\
\text { of-pipe }\end{array}$ & $\begin{array}{l}\text { Acq. of energy } \\
\text { products }\end{array}$ & & \\
\hline $\begin{array}{l}\text { Investment prod. } \\
\text { process }\end{array}$ & $\begin{array}{c}0.258 * * * \\
(0.082)\end{array}$ & & & & $\begin{array}{c}0.248 * * * \\
(0.086)\end{array}$ & & & & $\begin{array}{l}-0.194 \\
(0.144) \\
\end{array}$ \\
\hline $\begin{array}{l}\text { Investment end-of- } \\
\text { pipe }\end{array}$ & & $\begin{array}{c}0.250 * * * \\
(0.076)\end{array}$ & & & & $\begin{array}{c}0.239 * * * \\
(0.083)\end{array}$ & & & $\begin{array}{c}0.022 \\
(0.142) \\
\end{array}$ \\
\hline $\begin{array}{l}\text { Acquisition energy } \\
\text { products }\end{array}$ & & & $\begin{array}{c}0.799 * * * \\
(0.187)\end{array}$ & & & & $\begin{array}{c}0.743 * * * \\
(0.195)\end{array}$ & & $\begin{array}{c}0.902 * * * \\
(0.373)\end{array}$ \\
\hline ISO14001 & & & & $\begin{array}{c}0.476 * * * \\
(0.187)\end{array}$ & & & & $\begin{array}{c}0.683 * * * \\
(0.161) \\
\end{array}$ & $\begin{array}{c}0.128 \\
(0.260)\end{array}$ \\
\hline \multicolumn{10}{|l|}{ CONTROLS } \\
\hline Constant & $\begin{array}{c}8.203 * * * \\
(3.262)\end{array}$ & $\begin{array}{c}7.596 * * * \\
(3.427) \\
\end{array}$ & $\begin{array}{l}-1.722 \\
(4.424) \\
\end{array}$ & $\begin{array}{c}4.077 \\
(3.504) \\
\end{array}$ & $\begin{array}{c}8.826 * * * \\
(3.913)\end{array}$ & $\begin{array}{l}8.051 * * \\
(3.887) \\
\end{array}$ & $\begin{array}{l}-1.152 \\
(4.982) \\
\end{array}$ & $\begin{array}{c}0.855 \\
(2.765) \\
\end{array}$ & $\begin{array}{l}-7.676 \\
(4.719) \\
\end{array}$ \\
\hline Log Sales & $\begin{array}{l}-0.035 \\
(0.178) \\
\end{array}$ & $\begin{array}{c}0.007 \\
(0.176) \\
\end{array}$ & $\begin{array}{c}0.182 \\
(0.181) \\
\end{array}$ & $\begin{array}{c}0.300 \\
(0.189) \\
\end{array}$ & $\begin{array}{c}0.199 \\
(0.413) \\
\end{array}$ & $\begin{array}{c}0.133 \\
(0.401) \\
\end{array}$ & $\begin{array}{c}0.290 \\
(0.389) \\
\end{array}$ & $\begin{array}{l}-0.699 \\
(0.543) \\
\end{array}$ & $\begin{array}{l}-0.514 \\
(0.547) \\
\end{array}$ \\
\hline Human RD intensity & $\begin{array}{c}0.148 * * * \\
(0.060)\end{array}$ & $\begin{array}{c}0.162 * * * \\
(0.060)\end{array}$ & $\begin{array}{c}0.190 * * * \\
(0.061)\end{array}$ & $\begin{array}{c}0.076 \\
(0.076)\end{array}$ & $\begin{array}{c}0.559 * * * \\
(0.188)\end{array}$ & $\begin{array}{c}0.754 * * * \\
(0.187)\end{array}$ & $\begin{array}{c}0.544 * * * \\
(0.175)\end{array}$ & $\begin{array}{c}0.804 * * * \\
(0.319)\end{array}$ & $\begin{array}{c}0.780 * * * \\
(0.327)\end{array}$ \\
\hline Foreign capital & $\begin{array}{l}-0.699 \\
(1.606) \\
\end{array}$ & $\begin{array}{l}-0.479 \\
(1.547) \\
\end{array}$ & $\begin{array}{l}-1.477 \\
(1.515) \\
\end{array}$ & $\begin{array}{l}-0.119 \\
(1.340) \\
\end{array}$ & $\begin{array}{l}-0.095 \\
(1.727) \\
\end{array}$ & $\begin{array}{c}0.091 \\
(1.642) \\
\end{array}$ & $\begin{array}{l}-0.339 \\
(1.651) \\
\end{array}$ & $\begin{array}{c}0.522 \\
(1.457) \\
\end{array}$ & $\begin{array}{l}-0.260 \\
(1.403) \\
\end{array}$ \\
\hline $\begin{array}{l}\text { Importance to reduce } \\
\text { env. impact }\end{array}$ & $\begin{array}{c}0.008 \\
(0.013) \\
\end{array}$ & $\begin{array}{c}0.003 \\
(0.012) \\
\end{array}$ & $\begin{array}{c}0.006 \\
(0.012) \\
\end{array}$ & $\begin{array}{c}0.011 \\
(0.011) \\
\end{array}$ & $\begin{array}{l}-0.007 \\
(0.017)\end{array}$ & $\begin{array}{l}-0.007 \\
(0.016)\end{array}$ & $\begin{array}{l}-0.011 \\
(0.016)\end{array}$ & $\begin{array}{l}-0.004 \\
(0.013)\end{array}$ & $\begin{array}{l}-0.003 \\
(0.015) \\
\end{array}$ \\
\hline $\mathrm{M}($ Human RD) & & & & & $\begin{array}{c}-0.447 * * * \\
(0.199)\end{array}$ & $\begin{array}{c}-0.654 * * * \\
(0.198)\end{array}$ & $\begin{array}{c}-0.377 * * \\
(0.188)\end{array}$ & $\begin{array}{c}- \\
0.806 * * * \\
(0.332) \\
\end{array}$ & $\begin{array}{c}-0.665 * * \\
(0.347)\end{array}$ \\
\hline M(Foreign) & & & & & $\begin{array}{l}-0.263 \\
(4.304) \\
\end{array}$ & $\begin{array}{c}0.735 \\
(4.103) \\
\end{array}$ & $\begin{array}{l}-3.075 \\
(3.982) \\
\end{array}$ & $\begin{array}{c}0.485 \\
(3.826) \\
\end{array}$ & $\begin{array}{c}4.901 \\
(4.655) \\
\end{array}$ \\
\hline $\begin{array}{l}\text { M(Reduce env. } \\
\text { Impact) }\end{array}$ & & & & & $\begin{array}{c}0.026 \\
(0.027) \\
\end{array}$ & $\begin{array}{c}0.011 \\
(0.027) \\
\end{array}$ & $\begin{array}{c}0.038 \\
(0.025)\end{array}$ & $\begin{array}{l}0.037 * \\
(0.021) \\
\end{array}$ & $\begin{array}{l}0.049 * * \\
(0.025)\end{array}$ \\
\hline M(lsales) & & & & & $\begin{array}{l}-0.261 \\
(0.461) \\
\end{array}$ & $\begin{array}{l}-0.123 \\
(0.454) \\
\end{array}$ & $\begin{array}{l}-0.106 \\
(0.442) \\
\end{array}$ & $\begin{array}{c}1.084 * * \\
(0567)\end{array}$ & $\begin{array}{l}1.044 * * \\
(0.565) \\
\end{array}$ \\
\hline N. observations & 130 & 129 & 136 & 80 & 130 & 129 & 136 & 80 & 75 \\
\hline
\end{tabular}


Table 3. Effect of Regulation and Policy Measures

\begin{tabular}{|c|c|c|c|c|c|c|c|c|c|}
\hline & \multicolumn{4}{|c|}{ Random effects } & \multicolumn{5}{|c|}{ RE-Mundlak } \\
\hline & $\begin{array}{l}\text { Public } \\
\text { Funds }\end{array}$ & $\begin{array}{c}\text { Energy } \\
\text { taxes }\end{array}$ & $\begin{array}{l}\text { Env. } \\
\text { Taxes }\end{array}$ & Stringency & $\begin{array}{l}\text { Public } \\
\text { Funds }\end{array}$ & $\begin{array}{c}\text { Energy } \\
\text { taxes }\end{array}$ & $\begin{array}{c}\text { Env. } \\
\text { Taxes }\end{array}$ & Stringency & TOTAL \\
\hline Subsidies & $\begin{array}{c}0.613 * * * \\
(0.116)\end{array}$ & & & & $\begin{array}{c}0.746 * * * \\
(0.111)\end{array}$ & & & & $\begin{array}{c}0.486 * * * \\
(0.140)\end{array}$ \\
\hline Energy Tax & & $\begin{array}{c}0.331 \\
(0.254)\end{array}$ & & & & $\begin{array}{c}0.365 \\
(0.305)\end{array}$ & & & $\begin{array}{c}-0.382 \\
(0.272)\end{array}$ \\
\hline Pollution Tax & & & $\begin{array}{c}0.283 * * * \\
(0.127)\end{array}$ & & & & $\begin{array}{l}0.304 * \\
(0.179)\end{array}$ & & $\begin{array}{c}0.187 * * * \\
(0.092)\end{array}$ \\
\hline $\mathrm{CO} 2$ & & & & $\begin{array}{c}0.396 * * * \\
(0.145)\end{array}$ & & & & $\begin{array}{c}0.393 * * * * \\
(0.142)\end{array}$ & $\begin{array}{l}0.221^{*} \\
(0.132) \\
\end{array}$ \\
\hline \multicolumn{10}{|l|}{ CONTROLS } \\
\hline Constant & $\begin{array}{l}5.583 * \\
(2.974) \\
\end{array}$ & $\begin{array}{c}3.579 \\
(4.183) \\
\end{array}$ & $\begin{array}{c}11.19 * * * \\
(3.314)\end{array}$ & $\begin{array}{c}3.331 \\
(3.624) \\
\end{array}$ & $\begin{array}{c}4.555 \\
(2.973) \\
\end{array}$ & $\begin{array}{c}5.731 \\
(4.673) \\
\end{array}$ & $\begin{array}{c}11.26 * * \\
(5.614)\end{array}$ & $\begin{array}{c}3.126 \\
(4.011) \\
\end{array}$ & $\begin{array}{c}5.345^{* * *} * \\
(2.495)\end{array}$ \\
\hline Log sales & $\begin{array}{c}0.032 \\
(0.151)\end{array}$ & $\begin{array}{c}0.285 \\
(0.216)\end{array}$ & $\begin{array}{c}0.034 \\
(0.187)\end{array}$ & $\begin{array}{l}0.336^{*} \\
(0.196)\end{array}$ & $\begin{array}{c}0.516 \\
(0.377)\end{array}$ & $\begin{array}{c}0.498 \\
(0.357)\end{array}$ & $\begin{array}{c}0.031 \\
(0.422)\end{array}$ & $\begin{array}{c}0.525 \\
(0.353)\end{array}$ & $\begin{array}{c}0.224 \\
(0.531)\end{array}$ \\
\hline $\begin{array}{ll}\text { Human } & \text { RD } \\
\text { intensity } & \\
\end{array}$ & $\begin{array}{l}-0.034 \\
(0.057) \\
\end{array}$ & $\begin{array}{c}0.087 \\
(0.078) \\
\end{array}$ & $\begin{array}{c}0.374 * * * \\
(0.122) \\
\end{array}$ & $\begin{array}{l}0.119 * \\
(0.070) \\
\end{array}$ & $\begin{array}{c}0.550 * * * \\
(0.170) \\
\end{array}$ & $\begin{array}{c}0.612 * * * \\
(0.185) \\
\end{array}$ & $\begin{array}{c}0.381 \\
(0.318) \\
\end{array}$ & $\begin{array}{c}0.631 * * * \\
(0.184) \\
\end{array}$ & $\begin{array}{c}0.182 \\
(0.382) \\
\end{array}$ \\
\hline Foreign capital & $\begin{array}{c}0.084 \\
(1.470)\end{array}$ & $\begin{array}{l}-1.008 \\
(1.275)\end{array}$ & $\begin{array}{c}0.753 \\
(1.148)\end{array}$ & $\begin{array}{c}-0.729 \\
(1.213)\end{array}$ & $\begin{array}{c}2.036 \\
(1.609)\end{array}$ & $\begin{array}{c}0.116 \\
(1.317)\end{array}$ & $\begin{array}{c}0.608 \\
(1.264)\end{array}$ & $\begin{array}{c}0.234 \\
(1.299)\end{array}$ & $\begin{array}{c}1.071 \\
(1.700)\end{array}$ \\
\hline $\begin{array}{l}\text { Importance } \\
\text { reduce } \\
\text { impact }\end{array}$ & $\begin{array}{l}0.023 * * * \\
(0.011)\end{array}$ & $\begin{array}{c}0.003 \\
(0.014)\end{array}$ & $\begin{array}{l}-0.006 \\
(0.011)\end{array}$ & $\begin{array}{l}-0.002 \\
(0.013)\end{array}$ & $\begin{array}{l}-0.016 \\
(0.015)\end{array}$ & $\begin{array}{l}-0.005 \\
(0.017)\end{array}$ & $\begin{array}{c}0.003 \\
(0.017)\end{array}$ & $\begin{array}{l}-0.004 \\
(0.017)\end{array}$ & $\begin{array}{c}0.009 \\
(0.022)\end{array}$ \\
\hline M(Human RD) & & & & & $\begin{array}{c}-0.628 * * * \\
(0.181)\end{array}$ & $\begin{array}{c}-0.551 * * * \\
(0.204)\end{array}$ & $\begin{array}{c}-0.003 \\
(0.355)\end{array}$ & $\begin{array}{c}-0.550 * * * \\
(0.194)\end{array}$ & $\begin{array}{c}-0.031 \\
(0.380)\end{array}$ \\
\hline $\mathrm{M}$ (Foreign) & & & & & $\begin{array}{c}-4.316 \\
(3.238)\end{array}$ & $\begin{array}{l}-4.407 \\
(4.652)\end{array}$ & $\begin{array}{c}-0.040 \\
(5.371)\end{array}$ & $\begin{array}{l}-3.010 \\
(3.548)\end{array}$ & $\begin{array}{c}-0.624 \\
(2.371)\end{array}$ \\
\hline $\begin{array}{l}\text { M(Reduce env. } \\
\text { impact) }\end{array}$ & & & & & $\begin{array}{c}0.068 * * * \\
(0.021)\end{array}$ & $\begin{array}{c}0.011 \\
(0.028)\end{array}$ & $\begin{array}{l}-0.016 \\
(0.032)\end{array}$ & $\begin{array}{l}-0.001 \\
(0.025)\end{array}$ & $\begin{array}{l}-0.002 \\
(0.025)\end{array}$ \\
\hline $\mathrm{M}$ (lsales) & & & & & $\begin{array}{l}-0.498 \\
(0.406)\end{array}$ & $\begin{array}{l}-0.174 \\
(0.443)\end{array}$ & $\begin{array}{l}0.010) \\
(0.508)\end{array}$ & $\begin{array}{l}-0.133 \\
(0.416)\end{array}$ & $\begin{array}{l}-0.036 \\
(0.537)\end{array}$ \\
\hline $\mathrm{N}$ observations & 136 & 89 & 60 & 89 & 136 & 89 & 60 & 89 & 60 \\
\hline
\end{tabular}


Table 4. Robustness Diagnostics

\begin{tabular}{|c|c|c|c|c|c|}
\hline & IV & $\begin{array}{l}\text { Hausman - } \\
\text { Taylor }\end{array}$ & IV & $\begin{array}{l}\text { Hausman - } \\
\text { Taylor }\end{array}$ & \\
\hline $\begin{array}{l}\text { Dependent } \\
\text { Variable }\end{array}$ & \multicolumn{4}{|c|}{ Log of Environment R\&D investments } & $\begin{array}{c}\text { Log of } \\
\text { R\&D } \\
\text { Investments }\end{array}$ \\
\hline $\begin{array}{l}\text { Investment in } \\
\text { production } \\
\text { process }\end{array}$ & $\begin{array}{c}0.473 * * * \\
(0.124)\end{array}$ & $\begin{array}{c}0.120 \\
(0.096)\end{array}$ & & & \\
\hline Subsidies & & & $\begin{array}{c}1.072 * * * \\
(0.139)\end{array}$ & $\begin{array}{c}0.564 * * * \\
(0.143)\end{array}$ & $\begin{array}{c}0.892 * * * \\
(0.090)\end{array}$ \\
\hline Energy Tax & & & & & $\begin{array}{c}-0.286 * * * \\
(0.114) \\
\end{array}$ \\
\hline Pollution Tax & & & & & $\begin{array}{c}0.014 \\
(0.039) \\
\end{array}$ \\
\hline $\mathrm{CO} 2$ & & & & & $\begin{array}{l}0081^{*} \\
(0.055)\end{array}$ \\
\hline \multicolumn{6}{|l|}{ CONTROLS } \\
\hline Constant & $\begin{array}{c}4.615 \\
(3.463) \\
\end{array}$ & $\begin{array}{c}11.206^{* * * *} \\
(4.720)\end{array}$ & $\begin{array}{l}1.433 \\
(2.593) \\
\end{array}$ & $\begin{array}{l}6.427 * * \\
(3.577) \\
\end{array}$ & $\begin{array}{c}0.152 \\
(1.151) \\
\end{array}$ \\
\hline Log Sales & $\begin{array}{c}0.083 \\
(0.572)\end{array}$ & $\begin{array}{c}0.279 \\
(0.400)\end{array}$ & $\begin{array}{c}0.547 \\
(0.522)\end{array}$ & $\begin{array}{c}0.479 \\
(0.369)\end{array}$ & $\begin{array}{l}-0.001 \\
(0.223)\end{array}$ \\
\hline $\begin{array}{ll}\text { Human } \\
\text { intensity }\end{array}$ & $\begin{array}{c}0.379 \\
(0.282) \\
\end{array}$ & $\begin{array}{c}0.531 * * * \\
(0.183) \\
\end{array}$ & $\begin{array}{c}0.576 * * * \\
(0.258) \\
\end{array}$ & $\begin{array}{c}0.538 * * * \\
(0.167) \\
\end{array}$ & $\begin{array}{c}0.213 \\
(0.161) \\
\end{array}$ \\
\hline Foreign capital & $\begin{array}{l}-0.086 \\
(2.043)\end{array}$ & $\begin{array}{c}0.103 \\
(1.671) \\
\end{array}$ & $\begin{array}{c}2.701 \\
(1.896) \\
\end{array}$ & $\begin{array}{c}1.634 \\
(1.587) \\
\end{array}$ & $\begin{array}{c}2.401 * * * \\
(0.713)\end{array}$ \\
\hline $\begin{array}{l}\text { Importance to } \\
\text { reduce env. } \\
\text { impact }\end{array}$ & $\begin{array}{l}-0.012 \\
(0.020)\end{array}$ & $\begin{array}{l}-0.006 \\
(0.016)\end{array}$ & $\begin{array}{l}-0.019 \\
(0.018)\end{array}$ & $\begin{array}{l}-0.014 \\
(0.015)\end{array}$ & $\begin{array}{l}-0.004 \\
(0.009)\end{array}$ \\
\hline M(Human RD) & $\begin{array}{l}-0.251 \\
(0.291)\end{array}$ & $\begin{array}{c}-0.426 * * * \\
(0.199)\end{array}$ & $\begin{array}{c}-0.736 * * * \\
(0.272)\end{array}$ & $\begin{array}{c}-0.574 * * * \\
(0.183)\end{array}$ & $\begin{array}{l}-0.164 \\
(0.159)\end{array}$ \\
\hline $\mathrm{M}($ Foreign $)$ & $\begin{array}{l}-2.797 \\
(3.905) \\
\end{array}$ & $\begin{array}{c}1.110 \\
(5.082) \\
\end{array}$ & $\begin{array}{c}-6.027 * * \\
(3.063) \\
\end{array}$ & $\begin{array}{l}-3.369 \\
(3.708) \\
\end{array}$ & $\begin{array}{l}-0.575 \\
(0.994) \\
\end{array}$ \\
\hline $\begin{array}{l}\mathrm{M}(\text { Reduce env. } \\
\text { impact) }\end{array}$ & $\begin{array}{c}0.025 \\
(0.026) \\
\end{array}$ & $\begin{array}{c}0.028 \\
(0.131) \\
\end{array}$ & $\begin{array}{c}0.075^{* * * *} \\
(0.022) \\
\end{array}$ & $\begin{array}{c}0.063^{* * * *} \\
(0.024) \\
\end{array}$ & $\begin{array}{l}0.016^{*} \\
(0.010)\end{array}$ \\
\hline M(lsales) & $\begin{array}{l}-0.094 \\
(0.599) \\
\end{array}$ & $\begin{array}{l}-0.374 \\
(0.472)\end{array}$ & $\begin{array}{l}-0.474 \\
(0.541)\end{array}$ & $\begin{array}{l}-0.480 \\
(0.410)\end{array}$ & $\begin{array}{c}0.160 \\
(0.225)\end{array}$ \\
\hline $\mathrm{N}$ observations & 108 & 130 & 113 & 136 & 60 \\
\hline Instruments: & Lprevec $_{\mathrm{t}-1}$ & & Lfunds $_{\mathrm{t}-1}$ & & \\
\hline Rho & 0.375 & 0.719 & 0.302 & 0.616 & \\
\hline$\Sigma_{\mathrm{u}}$ & 0.627 & 1.084 & 0.476 & 0.813 & \\
\hline$\sigma_{\mathrm{e}}$ & 0.809 & 0.677 & 0.725 & 0.643 & 0.093 \\
\hline
\end{tabular}


ANNEX.

\section{TABLE A.1. DESCRIPTIVE STATISTICS BY INDUSTRY}

\begin{tabular}{|c|c|c|c|c|c|c|c|c|c|c|}
\hline \multicolumn{2}{|l|}{ Division (Manufacture) } & \multirow{2}{*}{$\begin{array}{c}\text { Environmental } \\
\text { R\&D } \\
\text { Igenv }\end{array}$} & \multirow{2}{*}{$\begin{array}{c}\text { Log of } \\
\text { Investment } \\
\text { in prod } \\
\text { process } \\
\text { Itratc }\end{array}$} & \multirow{2}{*}{$\begin{array}{c}\text { Log of } \\
\text { investment } \\
\text { in end-of- } \\
\text { pipe } \\
\text { Iprevc }\end{array}$} & \multirow{2}{*}{$\begin{array}{l}\text { Log of } \\
\text { Subsidies } \\
\text { Ifunds }\end{array}$} & \multirow{2}{*}{ 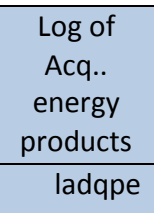 } & \multirow{2}{*}{$\begin{array}{l}\text { Log of energy } \\
\text { taxes } \\
\text { limpen }\end{array}$} & \multirow{2}{*}{$\begin{array}{c}\text { Log of Pollution } \\
\text { tax } \\
\text { limpcrn }\end{array}$} & \multirow{2}{*}{$\begin{array}{r}\begin{array}{r}\text { Log of } \mathrm{CO} 2 \\
\text { emissions }\end{array} \\
\text { Ico2 }\end{array}$} & \multirow{2}{*}{$\begin{array}{c}\text { Log of ISO14001 } \\
\text { LISO14001 }\end{array}$} \\
\hline & & & & & & & & & & \\
\hline \multirow{2}{*}{$\begin{array}{l}\text { Mining and Quarrying (CNAE 05, 06, } \\
07,08,09)\end{array}$} & Mean & 12.08039 & 15.25677 & 16.58808 & 7.064843 & 12.94175 & 11.39536 & 9.776195 & 8.144914 & 4.682436 \\
\hline & S.D & 0.412655 & 0.423075 & 0.7210219 & 1.289877 & 0.0807106 & 0.2027653 & 0.3857375 & 0.3067248 & 0.0614839 \\
\hline \multirow{2}{*}{$\begin{array}{l}\text { Food, beverages and tobacco } \\
\text { products (CNAE 10, 11, 12) }\end{array}$} & Mean & 13.17706 & 17.77701 & 17.45167 & 10.10737 & 14.61252 & 12.07144 & 9.583046 & 8.57816 & 6.661897 \\
\hline & S.D & 0.1607555 & 0.180851 & 0.4161457 & 0.2646669 & 0.0967118 & 0.0363557 & 0.3274098 & 0.0455154 & 0.1354946 \\
\hline \multirow[b]{2}{*}{ Textiles (CNAE 13) } & \multirow[b]{3}{*}{ Mean } & 11.12437 & 13.06516 & 14.33141 & 8.290161 & 12.30343 & \multirow{6}{*}{$\begin{array}{l}3.188543^{*} \\
0.1659827\end{array}$} & \multirow{6}{*}{$\begin{array}{l}3.093098^{*} \\
0.1989132\end{array}$} & \multirow{6}{*}{$\begin{array}{l}6.360258^{*} \\
0.0664117\end{array}$} & \\
\hline & & 0.3626502 & 1.549448 & 0.8744258 & 0.4924095 & 0.0426809 & & & & $4.48063^{*}$ \\
\hline & & 8.518127 & 9.777922 & 10.56094 & 6.376417 & 10.90586 & & & & 0.3251505 \\
\hline Wearing apparel (CNAE 14) & \multirow{3}{*}{ S.D } & 2.030922 & 1.918227 & 1.003625 & 1.599031 & 0.1764128 & & & & \\
\hline \multirow{2}{*}{$\begin{array}{l}\text { Leather and related product (CNAE } \\
\text { 15) }\end{array}$} & & 10.58244 & 13.28982 & 12.67526 & 6.913089 & 10.85892 & & & & 3.383358 \\
\hline & & 1.466575 & 0.430597 & 0.6817836 & 0.7568609 & 0.1284805 & & & & 0.2906951 \\
\hline \multirow{2}{*}{$\begin{array}{l}\text { Wood and of products of wood and } \\
\text { cork (CNAE 16) }\end{array}$} & Mean & 9.996566 & 14.2811 & 14.05089 & 7.372109 & 12.49167 & 10.4466 & 4.963522 & 6.523273 & 4.951707 \\
\hline & S.D & 1.019962 & 1.247445 & 1.26094 & 0.2872668 & 0.0807903 & 0.1665985 & 0.5112049 & 0.0594123 & 0.0830106 \\
\hline \multirow{2}{*}{$\begin{array}{l}\text { Paper and paper products, Printing } \\
\text { and reproduction of recorded media } \\
\text { (CNAE 17- 18) }\end{array}$} & Mean & 12.61 & 12.61 & 12.61 & 12.61 & 12.61 & 12.61 & 12.61 & 12.61 & 6.042333 \\
\hline & S.D & -0.35 & -0.35 & -0.35 & -0.35 & -0.35 & -0.35 & -0.35 & -0.35 & 0.117739 \\
\hline \multirow{2}{*}{$\begin{array}{l}\text { Coke and refined petroleum } \\
\text { products (CNAE 19) }\end{array}$} & Mean & 12.50685 & 18.31419 & 17.42093 & 7.764865 & 12.81993 & 13.15506 & 8.985047 & 9.685541 & 3.048275 \\
\hline & S.D & 0.1793831 & 0.1570783 & 0.2765784 & 0.6444038 & 0.3831499 & 0.1880609 & 0.3111324 & 0.0463505 & 0.3027128 \\
\hline \multirow{2}{*}{$\begin{array}{l}\text { Chemicals and chemical products } \\
\text { (CNAE 20) }\end{array}$} & Mean & 14.0311 & 17.63883 & 17.59881 & 9.71376 & 14.29883 & 11.45547 & 9.323435 & 8.914592 & 6.390927 \\
\hline & S.D & 0.1247197 & 0.3500376 & 0.262829 & 0.320496 & 0.1347729 & 0.1082172 & 0.3104618 & 0.052968 & 0.176693 \\
\hline \multirow{2}{*}{$\begin{array}{l}\text { Basic pharmaceutical products and } \\
\text { pharmaceutical preparations (CNAE } \\
\text { 21) }\end{array}$} & Mean & 11.48223 & 15.74799 & 15.94756 & 9.767017 & 11.91334 & 10.02105 & 0 & 3.338272 & 4.110952 \\
\hline & S.D & 0.4553958 & 0.2999834 & 0.2803137 & 0.2535548 & 0.1102054 & 0.0858916 & 0 & 0.181151 & 0.1850528 \\
\hline \multirow{2}{*}{$\begin{array}{l}\text { Rubber and plastic products (CNAE } \\
22 \text { ) }\end{array}$} & Mean & 13.0788 & 16.74853 & 15.53952 & 9.315876 & 13.25872 & 11.5089 & 6.847772 & 6.566814 & 5.901057 \\
\hline & S.D & 0.1367704 & 0.2398903 & 0.6932351 & 0.2834855 & 0.0409732 & 0.071793 & 0.3897748 & 0.071864 & 0.1346154 \\
\hline \multirow{2}{*}{$\begin{array}{l}\text { Other non-metallic mineral products } \\
\text { (CNAE 23) }\end{array}$} & Mean & 13.1301 & 17.40936 & 16.41807 & 8.809146 & 14.38527 & 11.10281 & 7.697777 & 10.38753 & 5.825871 \\
\hline & S.D & 0.2517128 & 0.5621892 & 1.31391 & 0.4985355 & 0.1555694 & 0.232286 & 0.3635794 & 0.1637158 & 0.1126027 \\
\hline
\end{tabular}




\begin{tabular}{|c|c|c|c|c|c|c|c|c|c|c|}
\hline \multirow[b]{2}{*}{ Basic metals (CNAE 24) } & Mean & 12.60724 & 17.0215 & 17.53507 & 9.27211 & 14.38418 & 11.68203 & 8.565221 & 9.385687 & \multirow{4}{*}{$\begin{array}{l}6.927365^{*} \\
0.0823018\end{array}$} \\
\hline & S.D & 0.3505099 & 0.6700175 & 0.4411209 & 0.3559253 & 0.0538688 & 0.1395025 & 0.3168831 & 0.0792614 & \\
\hline \multirow{2}{*}{$\begin{array}{l}\text { Fabricated metal products, except } \\
\text { machinery and equipment (CNAE 25) }\end{array}$} & Mean & 12.47116 & 15.48421 & 15.90794 & 9.743268 & 13.36432 & 10.95082 & 0 & 6.921757 & \\
\hline & S.D & 0.3939446 & 1.011297 & 0.5061088 & 0.4154086 & 0.0759348 & 0.1338505 & 0 & 0.0637574 & \\
\hline \multirow{2}{*}{$\begin{array}{l}\text { Computer, electronic, and optical } \\
\text { products (CNAE 26) }\end{array}$} & Mean & 12.50108 & 12.66136 & 13.25528 & 10.27998 & 10.63004 & 8.462883 & 0 & 4.868401 & \multirow{4}{*}{$\begin{array}{l}6.280338^{*} \\
0.0746493\end{array}$} \\
\hline & S.D & 0.1864332 & 0.8770544 & 0.9646092 & 0.3691578 & 0.1496987 & 0.2141272 & 0 & 0.1533109 & \\
\hline \multirow[b]{2}{*}{ Electrical equipment (CNAE 27) } & Mean & 13.33338 & 14.23526 & 15.70901 & 9.764332 & 12.02022 & 10.58122 & 6.038578 & 6.49611 & \\
\hline & S.D & 0.7982319 & 0.439076 & 0.673394 & 0.3442088 & 0.052555 & 0.0450498 & 0.3475729 & 0.1280055 & \\
\hline \multirow{2}{*}{$\begin{array}{l}\text { Machinery and equipment n.e.c. } \\
\text { (CNAE 28) }\end{array}$} & Mean & 13.06659 & 15.02121 & 14.4925 & 10.18035 & 12.08994 & 10.5406 & 5.132982 & 6.574629 & 6.395357 \\
\hline & S.D & 0.366482 & 0.6174741 & 1.172316 & 0.3680626 & 0.0591592 & 0.0950146 & 0.8476577 & 0.147046 & 0.1378229 \\
\hline \multirow{2}{*}{$\begin{array}{l}\text { Motor vehicles, trailers and semi- } \\
\text { trailers (CNAE 29) }\end{array}$} & Mean & 13.33936 & 15.03134 & 16.79294 & 9.979488 & 12.96703 & 11.16923 & 7.395905 & 7.270286 & \multirow{4}{*}{$\begin{array}{l}5.790369 * \\
0.2613724\end{array}$} \\
\hline & S.D & 0.9450325 & 0.8795857 & 0.6292211 & 0.5006133 & 0.0826277 & 0.0933435 & 0.3736554 & 0.0802471 & \\
\hline \multirow{2}{*}{$\begin{array}{l}\text { Other transport equipment (CNAE } \\
\text { 30) }\end{array}$} & Mean & 13.75005 & 14.31521 & 14.86456 & 12.05294 & 11.37456 & 9.361152 & 0 & 5.839557 & \\
\hline & S.D & 1.181771 & 0.6093658 & 0.43551 & 0.1221385 & 0.0748524 & 0.2071129 & 0 & 0.1392171 & \\
\hline \multirow[b]{2}{*}{ Furniture (CNAE 31) } & Mean & 11.22829 & 13.30584 & 13.93749 & 7.232455 & 11.79047 & \multirow{4}{*}{$\begin{array}{l}3.032443^{*} \\
0.1531099\end{array}$} & \multirow{4}{*}{$\begin{array}{c}3.00712^{*} \\
0.1624053\end{array}$} & \multirow{4}{*}{$\begin{array}{l}4.830277^{*} \\
0.2324247\end{array}$} & \multirow{4}{*}{$\begin{array}{l}5.362318^{*} \\
0.2455441\end{array}$} \\
\hline & S.D & 0.3066844 & 1.094522 & 1.602942 & 0.4150327 & 0.151354 & & & & \\
\hline \multirow{2}{*}{$\begin{array}{l}\text { Other manufacturing activities } \\
\text { (CNAE 32) }\end{array}$} & Mean & 10.44137 & 12.11526 & 13.82038 & 8.510214 & 10.75165 & & & & \\
\hline & S.D & 0.630669 & 0.8092662 & 0.8751639 & 0.4651875 & 0.07843 & & & & \\
\hline \multirow{2}{*}{$\begin{array}{l}\text { Repair and installation of machinery } \\
\text { and equipment (CNAE 33) }\end{array}$} & Mean & 11.31764 & 12.86406 & 13.30159 & 7.756545 & 11.16389 & 8.732975 & 0 & 4.030899 & \\
\hline & S.D & 0.5340272 & 0.6748466 & 1.034011 & 0.5974804 & 0.1715559 & 0.0802142 & 0 & 0.1817937 & \\
\hline \multirow{2}{*}{$\begin{array}{l}\text { Sewerage , Waste collection, } \\
\text { treatment and disposal activities; } \\
\text { materials recovery and Remediation } \\
\text { activities and other waste } \\
\text { management services (CNAE 37, 38, } \\
\text { 39) }\end{array}$} & Mean & 14.01708 & NA & NA & 8.40235 & 12.82014 & 10.33948 & 0 & 6.868012 & \\
\hline & S.D & 0.3783091 & NA & NA & 0.7532174 & 0.2728018 & 0.0854876 & 0 & 0.0615154 & \\
\hline
\end{tabular}

*Information only available agoregated for the whole sector 
Table A.2. The variables: definitions and sources

\begin{tabular}{|c|c|c|}
\hline Variables & Definitions & Source \\
\hline Environmental R\&D & $\begin{array}{l}\text { Business R\&D expenditure on the } \\
\text { control and care of the environment }\end{array}$ & $\begin{array}{l}\text { Statistics on R\&D activities } \\
\text { and Innovation in } \\
\text { Companies Survey, National } \\
\text { Statistics Institute of Spain } \\
\text { (INE) }\end{array}$ \\
\hline Sales & Annual Turnover & $\begin{array}{l}\text { Industrial Companies } \\
\text { Survey, INE }\end{array}$ \\
\hline $\begin{array}{l}\text { Human R\&D personnel } \\
\text { intensity }\end{array}$ & $\begin{array}{l}\text { Personnel in R\&D as \% of total } \\
\text { personnel }\end{array}$ & $\begin{array}{l}\text { Statistics on R\&D activities } \\
\text { and Innovation in } \\
\text { Companies Survey, INE }\end{array}$ \\
\hline Foreign capital & $\begin{array}{l}\text { Number of firms with more than } 50 \% \\
\text { of foreign capital as } \% \text { of total firms }\end{array}$ & $\begin{array}{l}\text { Statistics on R\&D activities } \\
\text { and Innovation in } \\
\text { Companies Survey, INE }\end{array}$ \\
\hline Subsidies & $\begin{array}{l}\text { Public subsidies to R\&D activities of } \\
\text { the firms }\end{array}$ & $\begin{array}{l}\text { Statistics on R\&D activities } \\
\text { and Innovation in } \\
\text { Companies Survey, INE }\end{array}$ \\
\hline $\begin{array}{l}\text { Investment in the production } \\
\text { process }\end{array}$ & $\begin{array}{l}\text { Investment in environmental } \\
\text { protection (integrated equipment and } \\
\text { facilities) }\end{array}$ & $\begin{array}{l}\text { Environmental protection } \\
\text { activities survey, INE }\end{array}$ \\
\hline Investment in end-of-pipe & $\begin{array}{l}\text { Investment in environmental } \\
\text { protection (independent equipment and } \\
\text { facilities) }\end{array}$ & $\begin{array}{l}\text { Environmental protection } \\
\text { activities survey, INE }\end{array}$ \\
\hline Acquisition of energy products & $\begin{array}{l}\text { Expenditure on acquisition of energy } \\
\text { products (electricity, gas and other } \\
\text { fuels) }\end{array}$ & $\begin{array}{l}\text { Industrial Companies } \\
\text { Survey, INE }\end{array}$ \\
\hline $\begin{array}{l}\text { Importance to reduce } \\
\text { environmental impact }\end{array}$ & $\begin{array}{l}\text { Firms that consider of high importance } \\
\text { the innovation objective "Reduce } \\
\text { environmental impact" (as \% of total } \\
\text { firms) }\end{array}$ & $\begin{array}{l}\text { Innovation in Companies } \\
\text { Survey, INE }\end{array}$ \\
\hline Energy taxes & Taxes on energy & $\begin{array}{l}\text { Environmental tax account, } \\
\text { INE }\end{array}$ \\
\hline Pollution taxes & Taxes on pollution and resources & $\begin{array}{l}\text { Environmental tax account, } \\
\text { INE }\end{array}$ \\
\hline $\mathrm{CO} 2$ emissions & $\begin{array}{l}\text { Carbon dioxide emissions into the } \\
\text { atmosphere of (thousands of tonnes of } \\
\text { equivalent } \mathrm{CO} 2 \text { ) }\end{array}$ & Air emissions account, INE \\
\hline ISO14001 & $\begin{array}{l}\text { Number of ISO } 14001 \text { certifications } \\
\text { per industry }\end{array}$ & $\begin{array}{l}\text { International Organization } \\
\text { for Standardization }\end{array}$ \\
\hline
\end{tabular}

Note: Information at industry level. 22 manufacturing sectors, period 2008-2013, Spain 